\title{
Comparison of the Graduate Education between Canada and China
}

\author{
Tao Tang ${ }^{1,2}$, Maged A. Aldhaeebi ${ }^{2}$, J. Q. Lan ${ }^{1} \&$ Ebrahim Bamanger ${ }^{3}$ \\ ${ }^{1}$ College of Electronic Engineering, Chengdu University of Information Technology, Chengdu 610225, China. \\ ${ }^{2}$ Department of Electrical and Computer Engineering, University of Waterloo, Waterloo N2L 3G1, Canada. \\ ${ }^{3}$ Department of Literacy, Culture, \& Language Education, Indiana University of Bloomington, Indiana, USA. \\ Correspondence: Tao Tang, College of Electronic Engineering, Chengdu University of Information Technology, \\ Chengdu 610225, China.
}

Received: March 8, 2020

Accepted: April 30, 2020

Online Published: May 12, 2020

doi:10.5430/ijhe.v9n4p13

URL: https://doi.org/10.5430/ijhe.v9n4p13

\begin{abstract}
In this study, a comparison of the graduate education program between Canada and China is presented. Compared with some developed countries in Europe and America, Canada's graduate education does not start too early. After World War II, especially in recent decades, its graduate education has developed rapidly. The reason is that under the situation of the rapid development of science, technology, and economy in domestic and foreign scale, the Canadian federal government and provincial government gradually realize the importance of graduate education; therefore, they vigorously support and fund graduate education. China's graduate education has started later than Canada's. However, it has developed rapidly in recent years. Canadian and Chinese graduate education have their distinct characteristics with some similarities and some differences. The development history, present situation and problems, training mode and future development of graduate education in Canada and China are compared, and then some suggestions for the development of graduate education in China are presented accordingly.
\end{abstract}

Keywords: graduate education, training mode, comparison, program

\section{Introduction}

Canada's graduate education has absorbed the world's advanced training mode and school philosophy. Coupled with the government's huge investment and various economic security systems. As a result, it has formed a high-quality system. Besides, graduate education in Canada attaches great importance to the combination of graduate education objectives and training methods with scientific research in universities. The graduate education in Canada works extensively with the government and enterprises to make it adapt to the needs of society. After decades of development, the Canadian graduate education has experienced "being subject to others" to "being independent", and has been one of the leading countries regarding the graduate education program in the world.

Compared with China, the development history of graduate education in China has more bumper. From the perspective of development, it has been in step with the social and economic development of China. It has proceeded through five stages of development including exploration, adjustment, development, and transformation. In addition, it has embarked on a path with Chinese characteristics from "decline" to "prosperity" and from "have" to "excellent".

In the first stage of development, there are not many differences in graduate education development between Canada and China. However, in just a few decades, Canada's graduate education has high ranked among the world's leading levels, although China's graduate education is relatively still in backward or low-level stages. The main reason that China's graduate education has not developed, is that the development of higher education in China has been stagnant for ten years, which was caused by the Chinese Cultural Revolution from May 1966 to October 1976, and is also related to the level of economic and social development in China.

In 2019, Sukhai (2019) introduced a study that mainly focused on the discussion of different types of graduate education in Canada. Moreover, some studies just focused on the graduate learning experiences of international students in universities (Beres, 2017; Moon, 2020; Bianco, 2016; Commander, 2016). Whereas, some studies explored the motivation of Chinese students for deciding to complete their graduate study in the Canadian universities (Zheng 2018; Rideout, 2019). Also, some studies presented a comparison of the teaching methods of graduate education between China and America (Guo, 2016). However, in the literature, few studies compared the 
overall profile of graduate education between Canada and China. So, this study presented the comparison in graduate education between Canada and China.

The remaining of the paper is organized as follows. The history of graduate education in Canada and China is presented in Section 2. In Section 3, the basic problems in graduate education levels in both countries are introduced. The fundamental developments in graduate education levels are provided in Section 4. In Section. 5, the researchers proposed some suggestions and solutions explained in detail. The last section concludes the paper and introduces its future research directions.

\section{The History of Graduate Education in Canada and China}

\subsection{The Development of Graduate Education in Canada}

Prior to 1960, most of the Canadian students completed their graduate education in the United States or Britain. Due to the rapid developments of economy, science, and technology in Canada, graduate education in the Canadian universities has undergone great changes and developments. Canadian universities generally establish extra effort to develop the graduate education level, which improves the quality of graduate education as well as increases the number of graduate students. As a result of these developments, recently Canada's graduate education system is considered one of the high-quality education systems in the world. The development stages can mainly conclude as follow:

(1) The first development period was started on Jan. 16, 1853 (middle and late 19th century to World War II). British royal parliament granted the Trinity College Canada which was considered as the first educational institute that award bachelors, masters, and doctor's degrees in the humanities. However, some Canadian universities did not provide their graduate students to graduate until the federation of Canada was founded in 1867. In 1885, the council of the University of Toronto approved a Ph.D. program and awarded the first Ph.D. in 1897, which was the beginning of doctoral education in Canada (Friedland, 2013).

(2) The second development period was established between the Second World War and the 1980s. Similar to the achieved developments in the graduate education system in some countries such as the UK, and the USA, the graduate education system in Canada started a period of great development after World War II. Since 1951, the federal government has invested directly in universities and increased its investment in the National Research Council (NRC) to fund graduate education. And with the expansion of the autonomy of universities, the federal government of Canada canceled the direct grant to universities in 1967 but allocated funds to provincial governments in the form of "transfer payments", which provided financial support for graduate education in universities. Besides, in 1960, 1977 and 1978, the federal government established the Canadian Medical Research Foundation (MRC), the Canadian Social and Human Sciences Research Foundation (SSHRC) and the Canadian Natural Sciences and Engineering Research Foundation (NSERC) to fund researchers and graduate students in institutions of higher learning and research (Advisory Panel, 2017).

(3) The last period of development is achieved in the period between the 1980s and 2020. Since the 1980s and due to intensive developments in the knowledge, economy and the increasingly fierce international competition, the Canadian federal government has constantly changed its position and role in graduate education through formulating policies. In early 1980, the federal government changed the traditional contract of responsibility for university administration with universities and provinces by modifying the post-secondary education assistance program, and invested funds in important projects related to the development of the national science, technology, and economy. In 1997, the federal government of Canada established the Canadian Innovation Foundation (CIF) to fund the infrastructure construction of Canadian universities, colleges, research hospitals, and non-profit research institutes.

All these provide policy guarantee and financial support for graduate education in Canada and promote the vigorous development of graduate education in related disciplines. After more than 30 years of development, graduate education in Canada is now at the forefront of higher education in the world. It has not only cultivated a large number of graduate students but also formed a complete system for the coordinated development of master's education and doctoral education. During this period, the Canadian Association of Graduate Studies (CAGS) was established. As a national organization of Graduate education, it made immeasurable contributions to the maturity and perfection of the Graduate education system in Canada.

\subsection{The Development of Graduate Education in China}

China's graduate education started relatively late, and its development can be divided into the following five stages:

(1) The first development period was started from 1949 to 1977. In the early days of the founding of the 200 People's 
Republic of China, Chinese graduate education abandoned the education model of Europe and America and began to learn from the Soviet Union, entering the exploratory period. At that time, Chinese universities were small in number, small in personnel, and short in research resources. The most important problem is that the scale of graduate education cannot meet the needs of national construction. In 1951, the government adopted the "Decision on Reforming the Academic System", which proposed that "research departments should be set up in universities and specialized colleges to recruit graduates of universities and specialized colleges or those with equivalent academic experience, and train teachers and scientific research talents in institutions of higher learning." In 1961, the "Provisional Work Regulations (Draft) of Higher Education Institutions Directly under the Ministry of Education" stipulated the training objectives, enrollment targets, admission methods, length of study, and training methods for postgraduate. However, since the start of the "cultural revolution" in 1966, postgraduate education in new China has been stagnant for 12 years, resulting in series of problems, such as lack of system construction, interrupted training of talents, and disordered teaching order.

(2) The second development period, which started from 1978 to 1988 is the growth period. Reform and Opening-up have opened a new era of graduate education in China. The decade of China's "cultural revolution" was the second "golden age" of economic development in developed countries such as the US, Japan, and Europe. And China's close neighbors, such as South Korea and Singapore, have also seized the opportunity to achieve great economic development. Facing this international situation, China at the beginning of Reform and Opening-up was eager for economic recovery and the return of higher education. In January 1978, the Ministry of Education issued the "Opinions on the Arrangement of Postgraduate Enrollment Work in Colleges and Universities in 1978" and decided to officially resume graduate admissions in that year. The development of graduate education in this period has three characteristics. First, the expansion of graduate education scale is comprehensive. Not only did it restore graduate admissions, but it also opened the door to study abroad. In August 1978, the Ministry of Education issued the "Notice on the Selection of Additional Students to Study Abroad ", which increased the number of dispatched students by 2,500 from the original $500(\mathrm{Mu}, 2013)$. Second, the construction of the graduate education system is standardized. In 1980, the "Degree Regulations of the People's Republic of China" was adopted to form and improve the Chinese degree system. In 1983, the "Professional Directory of Doctoral and Master Degrees Granted by Higher Education Institutions and Scientific Research Institutions (Trial Draft)" was issued, and for the first time, 11 disciplines, 64 first-level disciplines, and 647 second-level disciplines were divided. Third, the construction of the graduate education model is exploratory.

(3) The third development period which started from 1989 to 1998 is the adjustment period which takes ten years. The series of revolutions in Eastern Europe in 1989 and the collapse of the Soviet Union in 1991 put China at the crossroads of economic restructuring and severely challenged graduate education. In January 1992, Deng Xiaoping pointed out the way for China's economic construction. In October of the same year, China established the goal of establishing a socialist market economic system. With the reform of the economic system, China's graduate education construction faces two major difficulties. First, various industries have put forward new requirements for the scale, level, specialty, type, and quality of talents; second, traditional academic graduate training cannot meet the needs of the construction of a socialist market economy. For this reason, in 1992, the "Proposal on Granting Professional Degree Certificates by Major" was adopted, which reformed the way of granting degrees by disciplines only in the academic degree regulations, and divided academic degree and professional degree into two types for the first time. With the launch of the "Project 211 (a project of National Key Universities with the intent of raising the research standards of high-level universities and cultivating strategies for socio-economic development)", in 1996, the State Education Commission approved 33 universities to set up graduate schools and delegated the power to select doctoral supervisors and grant master degree programs. The number of graduate students increased significantly during this period, with the number of graduate students on campus increasing from 98,000 to approximately 198,000 (Wang, 1993).

(4) The third development period started from 1999 to 2009. At the turn of the century, China's graduate education has gone through 50 years, especially in the 20 years after the Reform and Opening-up, China's graduate education has completed the " foundation-based" construction. Not only the system is complete, and the scale develops rapidly, but also has cultivated a batch of talents with master's degree or above. During this period, China's postgraduate education adhered to a positive development orientation and achieved a new round of leaping growth in terms of the training scale, system construction, and theoretical innovation. With the promotion of "project 985 (a project to promote the development and reputation of the Chinese higher education system by founding world-class universities)", in 2002, the Degree Committee of the State Council reformed the degree authorization mechanism again, which stipulates that master's degree-authorized disciplines and majors should entrust provincial degree 
committees and universities with graduate schools to examine and approve by themselves. In 2008, in terms of the way of enrollment and training, the system of continuous study for master's and doctor's degree and supervisor's responsibility were implemented, which optimized the regional distribution of degree authorization and promoted the construction of degree authorization centers in western China.

(5) The last development period, which called transformation period started in 2010. In this period, five major breakthroughs occurred in China's graduate education including the number of postgraduate training units exceeded 800 , the number of graduate students on campus exceeded 2.7 million, the annual number of graduate students enrolled exceeded 850,000, the number of postgraduate tutors exceeded 400,000, and the number of foreign students studying in China exceeded 80,000. China's graduate education has also ushered in a shift from quantity to quality. Improving quality becomes the core task of graduate education.

In 2013, the Ministry of Education, the National Development and Reform Commission, and the Ministry of Finance jointly issued the "Opinions on Deepening Postgraduate Education Reform", which established the general idea of "service demand and improving quality". In 2014, the academic degree committee of the state council held the national conference on the quality of graduate education, which pushed China's graduate education to the "quality construction era".

\section{Current Situation and Challenges of Graduate Training}

\subsection{Current Situation in Canada}

The Growing number of graduate students increased between 1992 to 2004 . The number of masters increased by more than 20,000, while the number of doctors increased by nearly 10,000 (Statistical Report 2006). Fig. 1 shows the proportion of international students in the number of master students that increased from 13\% in 2004 to about $17 \%$ in 2014. The proportion of increased doctoral students is higher than master students by a percentage of $28 \%$ in 2014 (Statistical Report, 2016). Fig. 2 shows the proportion of female doctoral students that also increased from $36 \%$ in 1991 to $50.6 \%$ in 2016 (Chart 4, 2017).

The Canadian Colleges and Universities Association (AUCC) reported that the number of registered graduate students in 2009 increased by $7.2 \%$ compared with the 2008 year. In 2008 , the total number of people of working age in Canada was 26.92 million, among whom 1.69 million had received master or doctoral education, accounting for $6.3 \%$ of the total population (JOBS REPORT, 2014).

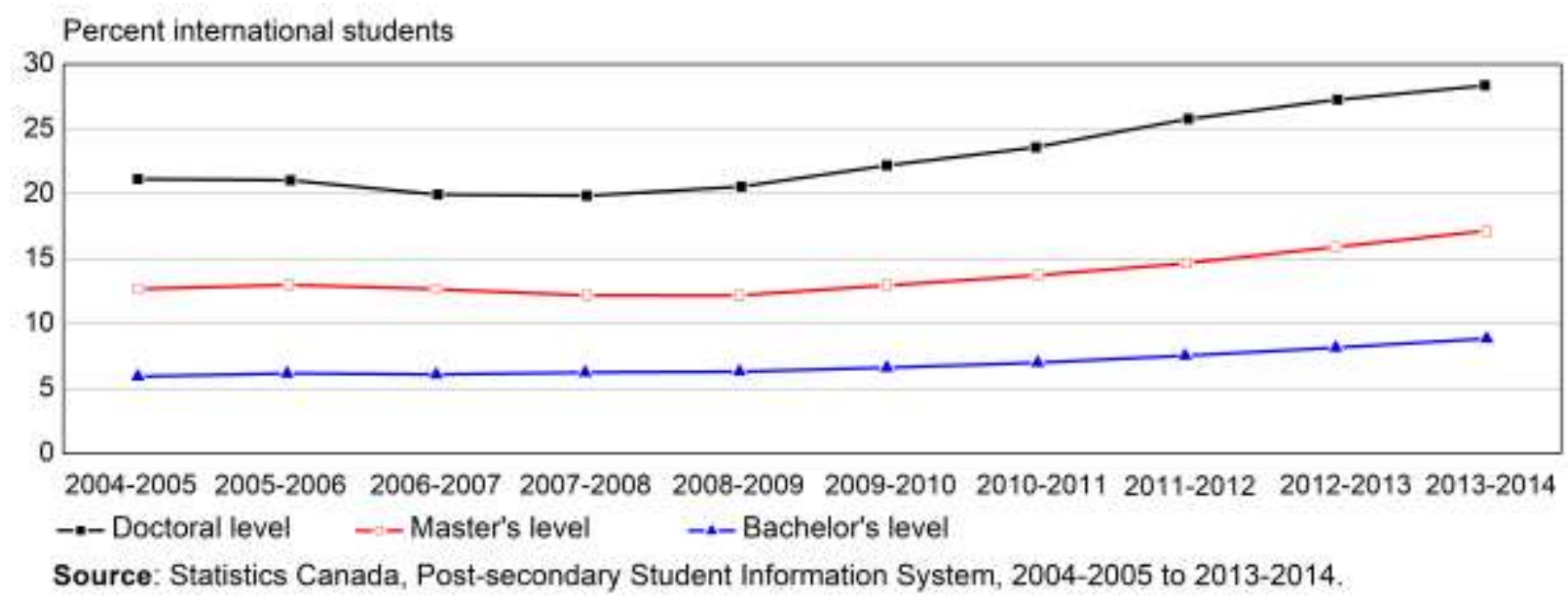

Figure 1. International students as a percentage of all university enrollments by program level (Bachelor's, Master's, or Doctoral), Canada, 2004-2005 to 2013-2014. 


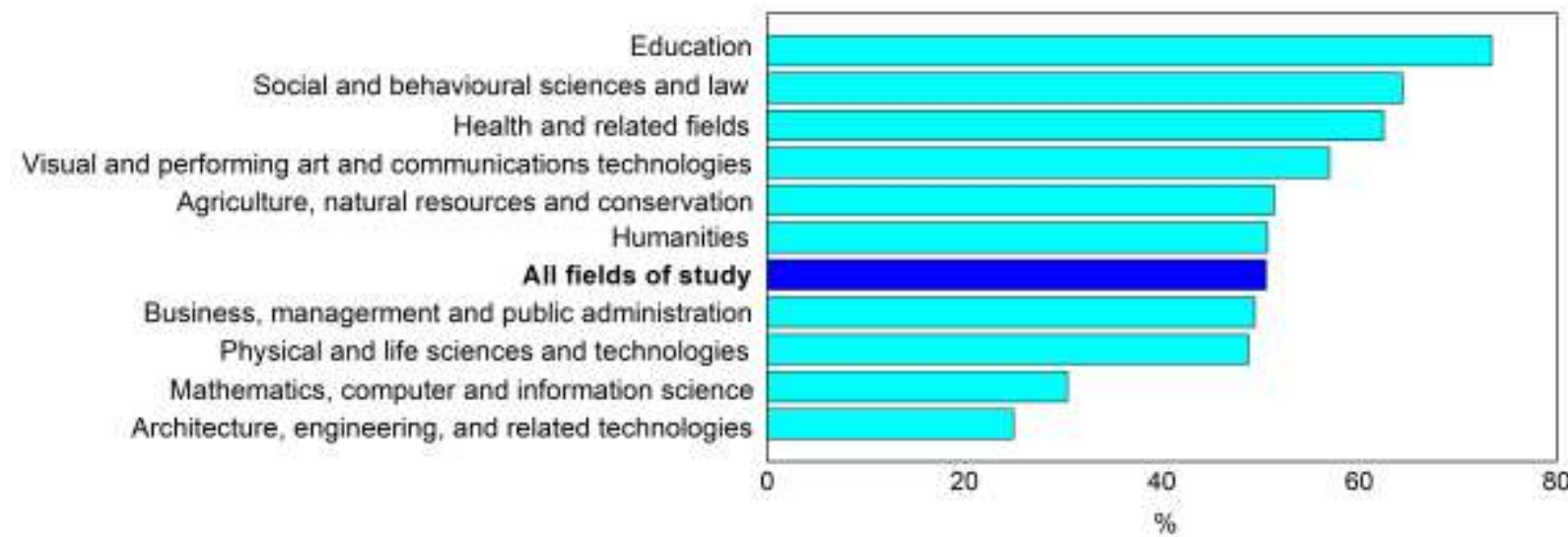

Figure 2. Fields of study ranked by percentage of women among young people aged 25 to 34 with an earned doctorate, Canada, 2016.

(1) Comparatively, comprehensive funding systems have been formed. For instance, the federal government established the National Research Council (NRC) in 1916. NRC was an important startling for federal and support funding to the universities in Canada. NRC provided the first public research funding and doctoral scholarship in the universities. After World War II, with the importance of universities in scientific research and national economic development, the federal government began to direct grants to universities, which enabled them to recruit more graduate students and conduct more scientific research of national interest. After the 1980s, the federal government increased investment in higher education through NSERC, CIHR, and SSHRC. Since the beginning of the new century, the proportion of federal government investment in universities has increased, especially in important research related to the nation's economic development.

(2) Trained a large number of workers and promoted the development of the Canadian economy. Investing in graduate education is a key feature of a knowledge-based economy, and of course, this investment can bring benefits. AUCC's 1998 report, "The Impact of Canadian University Research on the Economy," concluded that university research is a powerful driver of economic development and has an immeasurable impact on increasing GDP and employment opportunities. In 1998, university research contributed \$500 million to Canada's GDP growth and created 81,000 jobs and in 1999, universities contributed $\$ 210$ million in royalties, nearly 900 inventions, 350 patents, and 232 new licenses (Hall, 2019). A 2001 report by the university board of Ontario found that provinces received a direct or indirect return of about $\$ 320$ million from university research activities (COU Report, 2015).

\subsection{Challenges Facing Graduate Education in Canada}

After more than a century, graduate education development has achieved certain results in Canada. The knowledge economy and global competition have had an important impact on university research, policy, organization, and graduate training models. The shortage of high-quality labor force and the emphasis on national interests pose challenges to postgraduate education as the following:

(1) Most of the Canadian universities have low attended postgraduate students and low attended senior labor. Canada needs to attract more excellent talents to participate in graduate education due to relatively insufficient human resources. This is attracting will meet the needs of social development in the context of the development of the knowledge economy and the extensive demand for high-tech talents in the labor market. Fig. 3 shows the total number of graduate students in Canadian universities. The total number of graduate students in Canadian universities is still relatively low compared with the other countries, such as the US, Britain. (CBC Report, 2010). For example, about 4,200 candidates received a doctorate degree in Canada in 2005. That's about one-tenth of the numbers candidates received doctorates in the United States $(43,400)$ in the same year (Louise, 2015). 


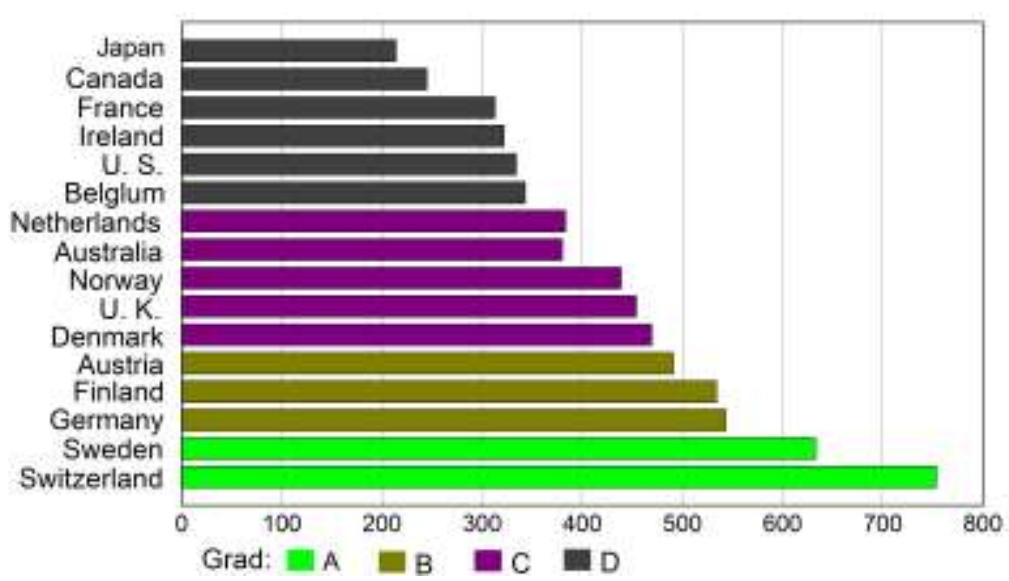

Figure 3. Ph.D. Graduates, 2010 (number of graduates in 2010 per 100,000 population age 25 to 29).

Recently, the Scientific and Technical Advisory Committee expert group said in a report on technology: "The pressure from economic, technological and scientific changes, as well as the aging workforce and global competition for skilled workers, will soon limiting the development of our technology these signs have already appeared ... Our education and training system has clearly felt this pressure (ACST, 1999)."

(1) Universities are faced with a shortage of instructors. There are three main reasons for this problem. First, $\mathrm{PhDs}$ are the main source of faculty in Canadian universities, and fewer than 4,000 $\mathrm{PhDs}$ are graduating each year in Canada, which directly leads to the shortage of qualified senior talents for universities to hire. Secondly, many university teachers are facing retirement and there are many vacant positions. Finally, the federal government's fiscal tightening may prevent many universities from having sufficient funds to hire teachers. AUCC pointed out that in 2006, the number of new faculty needed in Canadian universities was about 2,500 to 3,000, and by 2010, the demand could be more than 3,000 (Elliott, 2000).

(2) Reduced funding. Although the funding is increasing, compared with the increase in the number of graduate students, the proportion of funding is not enough. Due to the reduced federal budget, the funding of the three appropriation committees cannot cover most students. For example, CIHR's postgraduate scholarships are only available to $\mathrm{Ph}$.D. students who have registered and have been studying for a year, and about 800 people are funded each year. This amount is relatively low compared to the overall number of doctoral students. In NSERC, both masters and doctors are eligible for funding, but only about $10 \%$ of them receive funding.

(3) Deteriorating research facilities and the environment is considered as the main problem. Although Canada's college-age population is declining, university enrollments are generally on the rise as Canadians and international students seek employment advantages in a knowledge-based economy. The biggest challenge for the increase of students to universities is the lack of basic research facilities and the shortage of qualified tutors.

Faced with insufficient funding, universities' research environment has worsened by reducing programs, reducing the cost of faculty and staff, and delaying maintenance of classrooms, laboratories, and campuses, and increasing tuition to meet these needs. The increase in tuition fees also rejected some outstanding talents from graduate education, which weakened the university's scientific research and innovation capabilities.

\subsection{Current Situation in China}

In 1949, the People's Republic of China took over 107 graduate students who had graduated during the Republic of China and recruited the first 242 graduate students ( $\mathrm{Su}, 2000)$. This is a new starting point for graduate education in China. But before the Reform and Opening-up, the scale of graduate education was always small. During the 17 years from 1949 to 1965, the number of graduate students recruited in China was less than 24,000 (Wang, 2017).

After the Reform and Opening-up in 1978, the enrollment of graduate students has been expanding, from 10,700 in 1978 to 858,800 in 2018 and from 900 in 1981 to nearly 100,000 in 2018. By the end of 2018, China had 815 graduate education institutions and 2.7313 million graduate students, with the number of graduate students reached 604,400 for the first time (MOE, 2019). Table 1 shows the number of applicants has maintained a double-digit growth rate for four consecutive years. It reached to 3.41 million by 2020 (CEO, 2019).

With the increase in the number of graduate students, investment in education is also increasing. Table 2 shows the taking 117 universities directly under the administration of the constituent departments of the State Council of the 
People's Republic of China and their directly affiliated institutions as an example, from 2000 to 2010 . The number of graduate students in those universities increased from 175,000 to 690,000, with an average annual growth rate of $14.7 \%$, while the $R \& D(R \& D)$ expenditure increased from $\$ 1.18$ billion to $\$ 7.61$ billion with an average annual growth rate of $20.5 \%$. Correspondingly, the average R\&D expenditure of undergraduate students of those universities increased by more than 1.6 times from $\$ 6,714$ in 2000 to $\$ 11,000$ in 2010 , with an average annual growth rate of more than 5\% (Yuan, 2012).

The proportion of students who graduated in China is still very low. In 2009, China's human resources based on a percentage of $3.72 \%$ of graduated people in science and technology (Pang, 2011). In 2010, the percentage of employed who have graduated degrees from university is only $4 \%$. In the same year, there were 496,000 science and technology workers in R\&D institutions. $7.5 \%$ of workers had doctoral degrees and $27.1 \%$ of workers had graduate degrees or above. Among these institutions, 341,500 R\&D personnel are employed, only $12.24 \%$ of whom have doctoral degrees, and $38.89 \%$ of those who have graduate degrees or above (CSY, 2013). In 2001, China had only 23 graduate students per 100,000 populations.

With the continuous improvement of the international influence of China's graduate education, new changes have taken place in international students coming to China to study for graduate degrees. The total number of international graduate students in China in 1999 (2,896) was 8.67 times that of 1991 (334), of which the number of international doctoral students in China increased by 17.92 times between 1991 (50) and 1999 (896) (Wang, 2018).

Since the beginning of the $21^{\text {st }}$ century, with the expansion of the scale of international students, the focus of construction has shifted to system improvement and quality assurance. In 2016, the government issued "several opinions on doing a good job in the opening-up of education in the new era" and "promoting the co-construction of 'One Belt and One Road' education action". In 2017, the "Administrative Measures for the Recruitment and Training of International Students in Schools" was adopted. A series of policies have made the management of international students in China more flexible and gradually formed a legal, scientific, standardized, and socialized service system.

Table 1. The total number of graduate applicants and growth rate (\%), and the number of graduate admissions $(10,000)$ and the ratio of applicants and admissions $(\%)$.

\begin{tabular}{lcccc}
\hline time & Applicants & Growth rate & Admissions & Applicants and admissions ratio \\
\hline 2020 & 341 & 17.59 & $/$ & $/$ \\
2019 & 290 & 21.8 & 72 & $4.0: 1$ \\
2018 & 238 & 18.4 & 76.25 & $3.1: 1$ \\
2017 & 201 & 13.56 & 72.22 & $2.9: 1$ \\
2016 & 177 & 7.3 & 58.98 & $3.0: 1$ \\
2015 & 164.9 & -4.12 & 57.06 & $2.9: 1$ \\
2014 & 172 & -2.27 & 54.87 & $3.1: 1$ \\
2013 & 176 & 6.3 & 54.09 & $3.3: 1$ \\
2012 & 165.6 & 9.6 & 52.13 & $3.2: 1$ \\
2011 & 151.1 & 7.5 & 49.46 & $3.1: 1$ \\
2010 & 140.6 & 12.8 & 47.44 & $3.0: 1$ \\
\hline
\end{tabular}


Table 2. The number of graduate students $(10,000)$, the $R \& D$ fund ( $\$ 1$ million) and the R\&D of per undergraduate students $(\$ 1,000)$ in Colleges and universities directly under the administration of the constituent departments of The State Council of the People's Republic of China and their directly affiliated institutions

\begin{tabular}{lccc}
\hline Time & Graduate students & R\&D fund & Per student R\&D fund \\
\hline 2000 & 17.5 & 117.71 & 6.71 \\
2001 & 22.4 & 139.43 & 6.29 \\
2002 & 28.2 & 169.57 & 6.0 \\
2003 & 36.0 & 198.71 & 5.57 \\
2004 & 43.7 & 267.71 & 6.14 \\
2005 & 50.4 & 303.57 & 6.0 \\
2006 & 54.4 & 248.4 & 4.6 \\
2007 & 56.7 & 299.1 & 5.3 \\
2008 & 59.1 & 357.2 & 6.0 \\
2009 & 63.6 & 395.7 & 6.2 \\
2010 & 69.0 & 532.8 & 7.7 \\
\hline
\end{tabular}

Today, not only is China the largest destination for overseas students in Asia, but also the third largest one in the world. By the end of 2017, a total of 489,900 international students from 204 countries and regions came to study in China, accounting for $17.38 \%$ of the total number of international students in Asia, and its growth rate has remained above $10 \%$ for two consecutive years. Among them, there are more than 75,800 master and doctoral students, an increase of $18.62 \%$ over 2016 (CCG, 2017).

\subsection{Main Challenges of Graduate Education in China}

Compared with developed countries in education, there are still many problems in China's graduate education. In particular, the large-scale expansion of enrollment has highlighted some deep-level problems, which will inevitably bring serious consequences to the development of graduate education.

(1) Relative lack of educational infrastructure. The rapid increases in the number of graduate students, but the infrastructure of universities has not been improved. This situation has severely restricted the development of graduate education. The lack is mainly reflected in the following aspects: 1) Lack of literature. 2) Insufficient research funding. 3) No guarantee for experimental practice. 4) Weak academic atmosphere.

(2) The personal responsibility system of tutors has its disadvantages and drawbacks. These drawbacks includ: 1) Insufficient tutors themselves. Tutors cannot overcome their limitations in knowledge structure and schedule, and graduate students rarely learn from other tutors. The tutor's energy and time are limited, but the number of graduate students has increased greatly significantly. 2) Tutors lack the motivation to improve training quality. On the one hand, many universities implement the personal responsibility system for graduate tutors and give tutors full discretion. On the other hand, the evaluation of professional titles, employment, and allocation of funds seldom depend on the training quality of graduate students, so the tutor spends more time on project application and scientific research, and less time on guiding graduate students.

(3) Management cannot adapt to the need the ensure quality. At present, many universities have implemented mid-term assessments and external review systems for the thesis, but in practice, there is no effective assessment method, often with no certificate, no discussion, and no evaluation. In many universities, graduate tutors invite members of the graduate thesis defense committee and organize the thesis defense, which means that the inspection of product quality is handed over to producers.

(4) Institutional problems. In China, universities that undertake graduate education are publicly running. Government has a high degree of monopoly on graduate education resources. Graduate education resources are also allocated in full accordance with administrative orders. There is a huge contradiction between supply and demand, which is the main institutional obstacle that restricts the scientific development of graduate education. Besides, the government is too careful about the specific work of graduate education. The enrollment indicators, training specifications, the names and grades of degree awards are all approved by government departments. Finally, there is the problem of under-investment. Universities rely on the government, which inevitably leads to the problem of a single investment channel. 
Except the above problems, there are also some problems such as the contradiction between the expansion of postgraduate enrollment and the job demand and the disconnection between the major settings and needs.

\section{Comparison of Graduate Education Models}

\subsection{Admissions}

Graduate students do not need to take the entrance examination, but they must meet certain conditions: master's degree applicant must have a bachelor's degree, and the score in each subject at the university level must not be lower than B. For international students, a GRE or TOEFL score is also required. Applicants for doctoral degrees are generally required to have a master's degree, during which the average score of all subjects must be $\mathrm{B}+$, and at the same time, they also need to submit proof of certain research ability. Applicants are required to submit the following documents: application papers, application forms, and letters of recommendation, study and work histories, transcripts, research results, study objectives, and research plans.

The admission of graduate students in China is mainly based on the entrance examination. The entrance examination for graduate students is the Unified National Graduate Entrance Examination, which consists of preliminary and re-examinations. Generally speaking, the public subject such as political theory, foreign language, mathematics in preliminary examination is a unified proposition by the whole country, the major course is a proposition by admissions unit (UNGEE, 2019). The entrance examination for doctoral students also includes preliminary and re-examinations, which are independently organized by the admissions unit. For international students, the application system is generally adopted.

Some universities have adopted the method of recommendation without examination in the admission of the master's degree, to avoid the method of admission only based on scores. Nowadays, the proportion of graduate students recommended without examination increases year by year. For example, at Zhejiang University, $49.09 \%$ of students were exempt from admission in 2017 and 2018, and 54\% in 2019. In 2019, the proportion of majors in Peking University such as philosophy and religion, geography, particle physics and nuclear physics, Master of Insurance, statistics and higher education were 100\% (NGR, 2019). Besides, admissions of doctoral students in some universities have also begun to adopt the application system.

The separation of admission and training is the basic requirement to ensure fair admissions. But China's current mechanism combines admissions and training. Some colleges and universities are still increasing the role of tutors in admissions. At present, the application system for doctoral students in some schools can be decided directly by the interview of the tutors. At present, this mechanism is difficult to guarantee openness, fairness, and justice, and may even breed corruption, destroying the image of higher education in society.

\subsection{Canadian Graduate Education Model}

Canadian universities are administered by provincial governments and have great independence and autonomy in running their schools. Therefore, the training mode of graduates at each university is flexible. Graduate education in Canada presents multiple categories and levels according to scientific research, production, and social needs. According to the registration status, it is divided into two categories: full-time and part-time. According to the academic level of training and the corresponding training plan, it is mainly divided into the following three types: research degrees, professional degrees, and research degrees to promote professional development (CAGS, 2005)

(1) Research degrees are the most common type of registration status. Master's degree candidate students who strive to reach the master's degree through research courses and examinations. Doctoral candidate: the doctoral training plan usually includes the research of the degree project, the writing of the thesis, the publication of the thesis and the defense of the thesis, etc., as well as some teaching tasks.

(2) Professional degrees of the graduate level are designed to provide students with special skills and the necessary qualifications for a particular practice. Professional degrees are usually awarded at the master's level, such as speech-language pathology, library sciences, and MBA.

(3) Research degrees are the most important stage to promote professional development. Students who already have a professional qualification receive a graduate education to improve their professional knowledge and their research field. For example, they need to improve professional's skills, such as nursing, social work, education, and engineering. This type of research degree can be either a master's or doctoral level.

The multi-level, multi-category graduate education system makes Canadian postgraduate education very active, enabling many in-service graduates to study while working, and even to study for masters and doctorates after retirement, so that graduate education fully meets the needs of the scientific research, production and society, 
especially diploma or certificate graduate students are very useful for cultivating talents urgently needed in scientific research and enterprise departments.

The guiding ideology of Canadian graduate education is to guide students to actively carry out scientific exploration and research and encourage students' creative spirit. Under this step of the guidance, Canadian postgraduate education places strict requirements on the curriculum and teaching plan. Curriculum setting attaches great importance to interdisciplinary and cross-disciplinary. Students can learn not only cross-major, cross-department but also cross-school learning.

\subsection{Chinese Graduate Education Model}

Chinese graduate students also have full-time and part-time programs. They implement the same examination and enrollment policies and training standards, and their degree certificates have the same legal status and the same effect. Besides, graduates are divided into academic and professional, and the study time that is generally 2 to 3 years. The study time of doctoral degree generally takes between 3 to 4 years.

At present, the following changes are taking place in China's graduate education model: 1) the transformation to the application-oriented postgraduate training mode. In the training of application-oriented graduate students, the rapid development of part-time graduate education has become an effective mechanism to supplement the gap of applied talents. (2) Joint graduate training model. At present, the education director of Chinese graduate students has also changed from an "academic type" to a development path that places equal emphasis on "academic type" and "application type". At the same time, graduate education in China is actively expanding joint training models.

In 1984, some universities and scientific research institutes tried to jointly train postgraduate students. A new model of joint training first proposed established by universities and institutes (Wang, 2018). In 1987, the reform attempt of "double tutor joint training" was put forward, under the guidance of experts from universities and research institutes. In terms of doctoral training, to make up for the shortage of postgraduate education and training, the model of joint training with foreign countries was proposed in 1987, that is, after completing the basic courses in China, the graduate students were sent abroad to complete part or all of the doctoral thesis, and then returned to China to defend and apply for the degree. In 1989, the state encouraged enterprises to work closely with universities to provide them with scientific research topics, funding, and necessary working conditions to support joint training of graduate students, which became the source of "industry-university-research joint training ( $\mathrm{Li}, 2016)$." Nowadays, there are various forms of cooperation between the joint graduate training programs and graduate education in Chinese universities, including the establishment of overseas branch schools, overseas cooperation programs, and mutual recognition of academic degrees with other countries.

\section{The Future of Graduate Education}

\subsection{The Future Development Direction for Canada}

Looking forward to the future of graduate education in Canada, three main issues need to be answered theoretically and practically.

(1) Deal with the relationship between both the quantity and quality development of graduate education that is considered with limited government financial investment. Both the quantity and scale of graduate education in Canada is on the rise, and the proportion of the working-age population who has received graduate education is also increasing. However, because of the "lenient entry, strict exit" enrollment and training mechanism, the graduation rates remain low, which not only causes a waste of educational resources but also reflects that the overall quality of Canadian graduate education still needs to be improved.

(2) How should graduate education coordinate the relationship between personnel training, scientific research, and social services? To speed up the construction of the National Innovation System (NIS), the federal government of Canada has reduced its regular funding for graduate teaching and has invested a lot of funds in research fields that have strategic significance for knowledge innovation and universities with outstanding scientific research achievements. It has caused an imbalance in teaching and research within universities and has affected the overall quality of graduate education.

Besides, a postgraduate training model that can integrate teaching, research, and service is the goal pursued by all sectors of Canadian society. Among them, the Cooperative education mode can be described as a model for the integration of production, learning, and research in graduate education, how to enlarge its range of application in practice, so as to make it adapt to the development of the current international and domestic changes, is undoubtedly a research topic with theoretical significance and practical value. 
(3) The third step is the goal orientation and value orientation of graduate education. From the perspective of system theory, the "education system" as one of the social subsystems must be interdependent and influential with the social parent system. The reform and development of Canadian graduate education cannot be separated from the macro of its national innovation system construction and innovation strategy implementation. Therefore, postgraduate education in Canada should take "innovative talent cultivation" as its basic value orientation and ultimate goal.

\subsection{The Future Development Direction for China}

With the scale of graduate education is gradually expanding, the development direction of postgraduate education in China also needs to change.

(1) Shift to application-oriented. Pure academic postgraduate training can no longer meet the needs of national economic construction and social development. Therefore, new adjustments have been made in the layout and training model of postgraduate education in China. Especially in the past decade, the emergence of new materials, new energy, big data, "Internet plus" and other frontier fields has put forward new requirements for the training mode of graduate students. The school-enterprise joint training model has emerged to improve the suitability and matching of graduate education and industrial development.

(2) The first step is serving social needs. From "industrial development" to "scientific and technological innovation", China's graduate education is service-oriented and continuously meets the needs of society for high-quality graduate education. With the advent of the era of the knowledge economy, scientific and technological innovation and progress, it has become an important support for accelerating the transformation of the model of economic development, which is also the core demand of current social development.

The transition from "industrial development" to "scientific and technological innovation" determines the new content and new direction of social services for graduate education in China.

Since 2010 the number and proportion of graduate students participating in scientific research and scientific and technological innovation activities have increased significantly. Taking the national natural science foundation of China as an example, the proportion of graduate students participating in projects is on the rise. By 2017, the proportion of graduate participation in general programs, youth programs, and regional programs has reached $54.56 \%, 47.22 \%$, and $39.27 \%$, respectively (NSFC, 2017).

(3) Accelerating opening-up that shows from going global and bringing in step into coordinated development processes. Over the past 70 years, international exchanges and cooperation in graduate education in China have taken a distinctive path that is, "going global and bringing in "to" coordinated development.

From 1950 to 1965, China sent 10,600 government-funded students and scholars to the Soviet Union, Eastern Europe and other countries, of which 0.25 million were graduate students, accounting for $23.61 \%$ of the total (Zhang, 1984).

After the Reform and Opening-up, China's overseas education ushered in a new opportunity. The scale of Chinese-foreign cooperation in running schools has gradually expanded. By 2017, the number of cooperatively-run schools with master's degrees or above approved by the Ministry of Education has grown from 11 in 2010 to 40 in 2017 (MOE, 2017), For example, Tsinghua-Berkeley Shenzhen College, Shanghai New York University, Ningbo University of Nottingham, etc.

Besides, the number of graduate students participating in international academic conferences, overseas summer schools, overseas internships and other international exchange programs has also increased. At the same time, with the support of the Ministry of Education, Chinese universities have increased their efforts to run schools abroad. By the end of 2018, "China has established educational cooperation relationships with nearly 190 countries and regions, and signed agreements on mutual recognition of academic degrees with 50 countries and regions (Zhong 2018)."

\section{Inspiration to the Development of Postgraduate Education in China}

(1) Based on national conditions, develop multi-category and multi-level graduate education systems. The multi-category and multi-level graduate education system in Canada has enriched its graduate education, enabling much in-service staff who is interested in further study to working while studying. At the same time, because there is no age limit, many people can continue to participate in postgraduate studies after retirement, so this graduate training system also provides a platform for lifelong education.

(2) Lenient entry step and stringent exit process to ensure graduate quality. The scale of postgraduate enrollment in China has been gradually expanded and the difficulty of admission has been reduced moderately, but there are some problems in the quality of postgraduate training. It is more and more common for one tutor to guide multiple students. Due to the heavy academic work of the tutor himself, the tutor is unable to supervise the study of many students. 
This requires graduate managers to strengthen the academic management of graduate students based on a modest increase in enrollment and to ensure the quality of graduate education.

(3) A credit system and a flexible academic system should be adopted. Although the length of study for graduate students in Canada is regulated, the flexibility is relatively large. As long as the quality of postgraduate training can be guaranteed, they can be allowed to study, work and study at the same time, to broaden their social contact and enrich their practical knowledge. Therefore, it is suggested to change the length of our postgraduate study to 3 to 5 years to follow the rules of high-level talent training and scientific research.

(4) Graduate enrollment should change the method of scores destiny step. Canada's postgraduate enrollment emphasis on the comprehensive qualities and research capabilities of candidates and exam scores. The comprehensive quality and the evaluation of research ability should be focused on in the admissions. Multiple graduate admissions models should be tried.

(5) Set up a tutor group and let multiple tutors from different discipline backgrounds participate in the guidance. The guidance of the tutor group can solve the contradiction of a lack of tutors and an increase in students. At the same time, tutors with different academic backgrounds can ensure the interdisciplinary and personalized training of postgraduates.

\section{Conclusion}

In this study, a comparison of the graduate education program between Canada and China is introduced. In recent years, China's postgraduate education has developed rapidly. We have begun to think about the theoretical innovation and practical reform of graduate education and have achieved initial results. But most of this thinking and exploration still stay in the school level. The development of graduate education is one of the important measures to build an innovation-oriented country in China, and one of the important positions of scientific and technological innovation. Only by continuously learning the beneficial experience of graduate education abroad, including Canada, can we effectively improve the level and quality of graduate education in China. This work compares the development process, current status, training model, and future development direction of Canadian and Chinese graduate students, which provide reference and inspiration for the development of Chinese graduate students.

\section{Acknowledgements}

This work was supported in part by the National Study Abroad Fund of China (No. 201808515077), and in part by 2019 Collaborative Education Project of the Ministry of Education of China (No. 201901106001), as well as the 2018-2020 Sichuan provincial higher education talent training quality and teaching reform project (No. JG2018-534).

\section{References}

Advisory Panel on Federal Support for Fundamental Science (Canada). (2017). Investing in Canadas Future: Strengthening the Foundations of Canadian Research, available at: http://cins.ca/docs/ScienceReview_April2017.pdf (accessed 1 January 2019).

Beres, J. L. \& Woloshyn, V. E. (2017). Instructional insights gained from teaching a research methods course to Chinese international graduate students studying in Canada. Journal of International Students, 7(3), 728-743. https://doi.org/10.5281/zenodo.570030

Bouchard J. (2017). Learning from difference: comparative accounts of multicultural education. Current Issues in Language Planning, 18(1), 105-112, https://doi.org/10.1080/14664208.2016.1220282

CAGS. (2005). Your future: A Guide for Potential Graduate Students. available at: https://www.utm.utoronto.ca/careers/sites/files/careers/public/shared/pdf/your-future-a-guide-for-potential-grad uate-students.pdf (accessed 1 January 2019).

CCG. (2017). Blue book on international talents -- report on the development of Chinese students studying abroad. available at: http://www.sohu.com/a/212768959_271579 (accessed 1 January 2019).

Chart 4. (2017). Fields of study ranked by percentage of women among young people aged 25 to 34 with an earned doctorate. Canada, 2016, available at: https://www150.statcan.gc.ca/n1/daily-quotidien/171129/cg-a004-png-eng.htm (accessed 3 January 2019).

China Education Online. (2019). Number of applicants for postgraduate entrance examination in 2020 across the country, available at: http://www.eol.cn/e_ky/zt/common/bmrs/ (accessed 1 January 2019).

China statistical yearbook. (2013). Basic information on scientific and technological activities of scientific R\&D 
institutions, available at: http://www.stats.gov.cn/tjsj/ndsj/2013/indexch.htm (accessed 1 January 2019).

Commander, N., Zhao, Y., Gallagher, P. \& You, Y. (2016). Cross-national online discussions: international learning experiences with American and Chinese students in higher education. Innovations in Education and Teaching International, 53(4), 365-374. https://doi.org/10.1080/14703297.2015.1006524

COU Report. (2015). Inventory of Physical Facilities of Ontario Universities, available at: https://uwaterloo.ca/institutional-analysis-planning/sites/ca.institutional-analysis-planning/files/uploads/files/20 13report_june2015_final.pdf (accessed 1 January 2019).

Elliott L. (2000). Revitalizing Universities through Faculty Renewal. Research File, 4(n1), 11.

Friedland M. L. (2013). The University of Toronto - A History, Second Edition. Toronto: University of Toronto Press. https://doi.org/10.3138/9781442669154

GUO, Y. (2017). Comparison and Reflection on the Teaching Methods of Graduate Education between China and America. DEStech Transactions on Social Science, Education and Human Science, (etmi). https://doi.org/10.12783/dtssehs/etmi2016/11144

Hall B. \& Dragne C. (2019). The Role of the role of higher education for human and social development in the US and Canada. available at: https://upcommons.upc.edu/bitstream/handle/2099/7950/16\%20\%28259-273\%29.pdf?sequence=1\&isAllowed= y (accessed 1 January 2019).

Hettich, Walter. (1971). Expenditures, output and productivity in Canadian university education. Special Study, 14, Ottawa, Economic Council of Canada. 123.

Hunter, M. T. \& McDavid, J. C. (2019). Comparison of Canadian and American Graduate Evaluation Education Programs. Canadian Journal of Program Evaluation, 34(2), 207-234. https://doi.org/10.3138/cjpe.56989

Jobs Report. (2014). Jobs report: the state of the Canadian labour market. available at: https://www.budget.gc.ca/2014/docs/jobs-emplois/pdf/jobs-emplois-eng.pdf (accessed 1 February 2019).

Li j. L., Wan M. \& Pei X. (2016). On History, Characteristics and Tendency of Policy Reform and Implementation in Joint Postgraduate Cultivation in China. Journal of Graduate Education, 6, 8--12.

Louise D. \& Darren K. (2015). Expectations and Labour Market Outcomes of Doctoral Graduates from Canadian Universities. available at: https://www150.statcan.gc.ca/n1/pub/81-595-m/81-595-m2011089-eng.htm (accessed 1 January 2019).

MOE. (2017). List of Chinese-foreign cooperatively-run schools with Master's degree or above. available at: http://www.crs.jsj.edu.cn/aproval/orglists/1 (accessed 1 January 2019).

MOE. (2019). The number of schools increased by more than 5,000, the number of students increased by more than 5 million, and the number of full-time teachers increased by 460,000. available at: http://www.moe.gov.cn/fbh/live/2019/50340/mtbd/201902/t20190228_371560.html (accessed 3 January 2019).

Moon, C. Y., Zhang, S., Larke, P. \& James, M. (2020). We Are Not All the Same: A Qualitative Analysis of the Nuanced Differences Between Chinese and South Korean International Graduate Students Experiences in the United States. Journal of International Students, 10(1). https://doi.org/10.32674/jis.v10i1.770

MU W. S. \& Ma C. (2013). Review and reflection on international cooperative training of Chinese graduate students since the Reform and Opening-up. Journal of Zhengzhou University, 46(3), 88--91. http://dx.doi.org/10.22459/CYRD.07.2018

NGR. (2019). National graduate student survey report. available at: https://new.qq.com/rain/a/20191228A0IRJU00 (accessed 8 January 2019).

NSFC. (2017). Statistics of national natural science foundation of China (2017). available at: http://www.nsfc.gov.cn/publish/portal0/ (accessed 1 January 2019).

Pang C. G. (2011). China Talent Development Report (2011). Beijing: Social Science Literature Press. 77

Report of the Expert Panel on Skills. (1999). Stepping up: skills and opportunities in the knowledge economy. available at: http://publications.gc.ca/collections/Collection/C2-467-2000E.pdf (accessed 21 January 2019).

Rideout, G. \& Tabrizi, S. (2019). Chinese Students Initially Disclosed Reasons for Studying in Canada. International Journal for Cross-Disciplinary Subjects in Education, 9(3), 3444-3453. 
https://doi.org/10.20533/ijcdse.2042.6364.2018.0461

Statistical Report. (2006). $36^{\text {th }}$ statistical report : $1992-2004$ available at: https://cags.ca/documents/stats/36StatisticalReport.pdf (accessed 1 January 2019).

Statistical Report. (2016). International students in Canadian Universities, 2004-2005 to 2013-2014. available at: https://www150.statcan.gc.ca/n1/pub/81-599-x/81-599-x2016011-eng.htm (accessed 6 May 2019).

Su W. N. (2000). General history of Chinas education system (vol. 8). Jinan: Shandong education press, 425.

Sukhai, A. (2019). Minding the Gap: Perspectives on Graduate Education for Students with Disabilities. Preparing Students for Life and Work. Brill Sense, 64-77. https://doi.org/10.1163/9789004393073_004

The Conference Board of Canada Report. (2010). PhD Graduates. available at: https://www.conferenceboard.ca/HCP/Details/education/Phd-graduates.aspx (accessed 1 January 2019).

UNGEE. (2019). Unified National Graduate Entrance Examination. available at: http://www.360doc.com/content/19/0901/20/48912848_858530516.shtmln (accessed 9 May 2019).

Wang T. J. (1993). Focus on economic construction and vigorously develop education. Journal of shandong medical university (social science edition), 1, 4--6.

Wang Z. J. \& Qiao G. (2018). Achievements and prospects of graduate education in China in the past 40 years of Reform and Opening-up. Academic Degrees \& Graduate Education, 12, 7--13.

Wang Z. J. (2018). Chinese degree and postgraduate education for 40 years (1978-2017). Beijing: China science and technology press. 124

Wang Z. K. (2017). Graduate education yesterday, today and tomorrow available at: http://www.qstheory.cn/science/2017-10/24/c_1121846433.htm (accessed 5 June 2019).

Yuan B. T., Wang D. M. \& Liu F. (2012). Is the Enrollment of Graduate Students too large for China. Journal of Higher Education, 33(8), 53--58.

Zhang J. (1984). Yearbook of Chinese education (1949-1981). Beijing: China encyclopedia press. 980

Zheng, J. (2018). International Student Mobility, Government Policies, and Neoliberal Globalization: Exploring Chinese Graduate Students Perspectives on Pursuing Higher Education in Canada. In International Student Mobility and Opportunities for Growth in the Global Marketplace (pp. 49-63). https://doi.org/10.4018/978-1-5225-3451-8.ch004

Zhong Y. P. (2018). Reform is a powerful engine of education modernization--pay tribute to the 40th anniversary of Reform and Opening-up. available at: http://www.moe.gov.cn/jyb_xwfb/s5148/201812/t20181218_363869.html. (accessed 3 July 2019). 